\title{
Non-complicated cholelithiasis associated with GERD. Results of combined laparoscopic surgery in low risk patients
}

\author{
F. Pozo, F. Giganto ${ }^{1}$ and L. Rodrigo ${ }^{2}$ \\ Service of General Surgery and Digestive Diseases. ${ }^{1}$ Unit of Motiliy. ${ }^{2}$ Service of Digestive Diseases. Hospital Central de \\ Asturias. Oviedo, Spain
}

\begin{abstract}
Objectives: the aim of this study was to evaluate the efficacy of combined laparoscopic surgery for non-complicated cholelithiasis and gastroesophageal reflux disease (GERD) in patients with low surgical risk.

Methods: a total of 680 cholecystectomies performed by means of laparoscopic surgery were retrospectively studied from February 1991 to February 2002. A total of 442 patients that fulfilled the inclusion criteria were divided into two groups: group A: non-complicated cholelithiasis (cholecystectomy alone), consisting of a total of 362 patients, and group B: non-complicated cholelithiasis and GERD (cholecystectomy and Toupet's fundoplication in all cases) in 80 patients. Demographic and clinical data, intraoperatory incidences, and post-surgical complications were prospectively collected and compared for all patients. The results of reflux surgery (group B) were evaluated at 6 months by means of 24hour $\mathrm{pH}$-metry.

Results: in spite of the fact that the group undergoing combined surgery consisted of patients with greater weight and older age ( $p<0.05)$, no significant differences were found in the number of intraoperative incidences and post-surgical complications between both groups (NS). Significant differences were only found in the duration of surgery: $48 \pm 25 \mathrm{~min}(10-150)$ in group A compared to $112 \pm 23 \mathrm{~min}(80-180)$ in group $B(p<0.001)$, and in the return to normal daily activities $(5.8 \pm 0.9$ days vs $6.5 \pm 1$ days in group $B)(p<0.001)$. In the latter group a normalization of 24-hour pH-metry values and an absence of symptoms associated with reflux were observed in all cases.

Conclusions: in patients younger than 75 years with low surgical risk and non-complicated cholelithiasis and GERD, both illnesses can be resolved during the same surgical procedure by laparoscopy with no increased risk or postoperative complications.
\end{abstract}

Key words: Laparoscopic cholecystectomy. Gastroesophageal reflux. Toupet's fundoplication. Endoscopic surgery.

Recibido: 23-06-03.

Aceptado: 22-09-03.

Correspondencia: Luis Rodrigo. Servicio de Aparato Digestivo. Hospital Central de Asturias. C/ Celestino Villamil, s/n. 33006 Oviedo. Telf.: 98510 80 58. Fax: 9852736 14. e-mail: 1rodrigos@terra.es
Pozo F, Giganto F, Rodrigo L. Non-complicated cholelithiasis associated with GERD. Results of combined laparoscopic surgery in low risk patients. Rev Esp Enferm Dig 2004; 96: 237-245.

\section{INTRODUCTION}

In the last decade endoscopic surgery has been established as the treatment of choice for symptomatic biliary cholelithiasis both in its simple and complicated forms (1-5). Different demographic characteristics exist in patients (age, classification according to the American Society of Anesthesiology -ASA-, and form of presentation) that may influence the decision of an endoscopic approach or even its conversion to open surgery once indicated (6-8).

On the other hand, we know that a subgroup of patients with cholelithiasis presents associated illnesses in the upper gastrointestinal tract, such as gastro-esophageal reflux disease (GERD) (9).

Furthermore, evidence exists showing that surgery for cholelithiasis alone, either open surgery or laparoscopic, may cause or impair GERD (10), and that symptoms of reflux are more common after laparoscopic cholecystectomy than in the rest of the population (11). Part of the clinical failure that patients suffer when undergoing cholecystectomy may be due to the presence of associated gastroesophageal reflux $(11,12)$; thus, if this is resolved, the frequency of "post-cholecystectomy syndrome" can be considerably reduced (11-13).

It therefore seems reasonable to systematically look for the presence of GERD prior to surgery for cholelithiasis, and to try to resolve both illnesses during the same surgical procedure. In this way later surgery may be avoided.

Prior to the development of laparoscopic surgery, our group always performed combined surgery in the same pro- 
cedure whenever possible, if we knew of the presence of both illnesses. However, in laparoscopic surgery, we do not currently possess clear evidence that combined surgery is absolutely necessary.

Therefore, the aim of this study was to evaluate surgery duration, conversion rates of endoscopic to open surgery, development of complications and nature thereof in a group of patients in whom these two illnesses (cholelithiasis and GERD) had been resolved during one single endoscopic procedure.

Given the low level of experience in general, our main goal was to conduct an evaluation of surgical results in a group of patients with low surgical risk, according to the criteria issued by the American Society of Anesthesiology (ASA-1 and ASA-2) and younger than 75 years of age. In order to make a correct evaluation, this group was compared with another with similar characteristics, which had only undergone surgery for non-complicated cholelithiasis.

\section{MATERIAL AND METHODS}

Laparoscopic surgery for cholelithiasis was performed in a total of 680 consecutive patients between February 1991 and February 2002. All operations were performed by the same surgeon (FP).

The study protocol included: demographic characteristics of the patients, clinical history, physical examination, duration of symptoms, blood biochemistry, electrocardiogram, chest radiography, and abdominal ultrasonography. In cases where patients referred symptoms of GERD, an upper gastrointestinal endoscopy was performed to confirm this diagnosis. If no erosive lesions were present, a 24-hour pH-metry was performed after locating the lower esophageal sphincter (LES) by means of stationary manometry. This test was also made in all patients with esophagitis prior to surgery.

Esophageal manometry and $\mathrm{pH}$-metry were repeated 6 months after surgery in all patients operated on for GERD. In addition, intervention details and the post-surgical history were prospectively collected.

Operation time was defined as the duration of the procedure from the beginning of the skin incision to the completion of the skin closure.

Esophageal manometry was performed with a lowcompliance hydro-pneumocapilary perfusion system using a stationary pullthrough technique with a catheter including four orifices $5 \mathrm{~cm}$ apart from one another.

Twenty-four-hour $\mathrm{pH}$ monitoring was made using a Mark III ambulatory recorder (Synectics Medical, Irving, Texas) with a sampling frequency every 4 seconds. This recorder was connected to a monocrystaline antimonium electrode placed $5 \mathrm{~cm}$ above the upper part of LES, which was previously determined by manometry, and following a calibration at $\mathrm{pH}$ solutions of 1.07 and 7.01. This test was abnormal when the percentage of total acid exposure was over $4 \%$ and the DeMeester score was above 14.24 points.

In all cases prior to surgery, the presence of a primary motor esophageal disorder (achalasia, diffuse esophageal spasm, symptomatic peristalsis) was ruled out, since its presence may lead to confusion while interpreting the symptoms exhibited by patients.

In case of clinical suspicion, or of chemically- and/or ultrasonographically-demonstrated choledocholithiasis, an endoscopic retrograde cholangiography (ERCP) and an endoscopic sphincterotomy (ES) for the removal of stones from the main bile duct were undertaken.

\section{Inclusion criteria}

Patients were divided into two groups according to the following criteria:

Group A (non-complicated cholelithiasis). Included patients with previous clinical episodes of biliary colic and ultrasonographic evidence of biliary lithiasis or microlithiasis.

Group B (non-complicated cholelithiasis plus GERD). Patients included in this group were similar to those in group A with associated GERD; they also met the following criteria: a) patients who presented symptomatic GERD, demonstrated by endoscopy and/or abnormal 24hour $\mathrm{pH}$ monitoring, and whose symptoms (mainly regurgitations) were not adequately controlled with medical treatment (usually with proton bomb inhibitors), or those who had symptoms relieve but compliance was not adequate; and b) patients with complications secondary to persistent GERD, such as esophageal stenosis, Barrett's esophagus, respiratory symptoms, or chronic anemia due to esophageal bleeding.

Reasons for exclusion were: choledocholithiasis not resolved endoscopically, suspicion of gallbladder carcinoma, associated condition requiring open surgery, nontreatable coagulation disturbances, age over 75 years, and patients in ASA groups 3 and 4. The presence of choledocholithiasis was not considered a contraindication if this was previously resolved by ERCP.

\section{Surgical techniques}

Cholecystectomy was performed in both groups, A and $\mathrm{B}$, using the surgical technique proposed by Dubois (1) with variations depending on the anatomy of the patient and the existence of previous surgery in the supramesocolic space.

The same technique was employed in all patients in group B. A retroesophageal suture of the diaphragmatic crura and posterior Toupet's fundoplication was made in order to resolve GERD. This technique has been described by our group in a previous study (14). 
Table I. Demographic and clinical data

\begin{tabular}{|c|c|c|c|}
\hline & Group A $(n=362)$ & Group B $(n=80)$ & $p$ \\
\hline Age (years) & $49.6 \pm 13(19-75)$ & $56 \pm 11(32-74)$ & $<0.05$ \\
\hline Sex ratio M:F & $251 / 111=2.3 / 1$ & $35 / 45=1.1 / 1.3$ & $<0.05$ \\
\hline No. of pregnancies and deliveries & $1.4 \pm 1.5(1-5)$ & $1 \pm 1.3(1-11)$ & NS \\
\hline BMI $25-30, n(\%)$ & $122(33,7 \%)$ & $23(28.7 \%)$ & $<0.05$ \\
\hline BMI 30-40, n (\%) & $130(35.9 \%)$ & $36(45 \%)$ & $<0.05$ \\
\hline $\mathrm{BMI}>40, \mathrm{n}(\%)$ & $50(13.8 \%)$ & $19(23.8 \%)$ & $<0.05$ \\
\hline Previous infraumbilical laparotomy & $94(26 \%)$ & $11(13.7 \%)$ & NS \\
\hline Clinical onset time (weeks) & $43 \pm 35.4(1-99)$ & $42 \pm 34.7(2-99)$ & NS \\
\hline Diabetes, n (\%) & $13(3.6 \%)$ & $2(2.5 \%)$ & NS \\
\hline Arterial hypertension, $\mathrm{n}(\%)$ & $31(8.6 \%)$ & $16(20 \%)$ & $<0.05$ \\
\hline
\end{tabular}

$\mathrm{BMI}=$ body mass index $\left(\mathrm{kg} / \mathrm{m}^{2}\right)$

A prophylactic dose of antibiotics (875 $\mathrm{mg}$ amoxycillin plus $125 \mathrm{mg}$ clavulanic acid) was administered to all patients before surgery, and thromboembolic prophylaxis was started preoperatively with low molecular weight heparine, which was administered subcutaneously on a daily basis and maintained for 10 days.

In all cases, patients were operated on by the same surgeon (FP), who had previously performed a total of 180 cases of laparoscopic cholecystectomy.

\section{Statistical analysis}

Standard statistical methods were used to evaluate various univariate relationships. Group differences were evaluated using the two-sample $t$ test, and the Chi square test when appropriate. All calculated $p$ values were two sided, and $\mathrm{p}$ values $<0.05$ were considered statistically significant.

\section{RESULTS}

Out of a total of 680 consecutive patients who underwent surgery, $125(18.4 \%)$ patients aged over 75 years and/or classed as ASA-3 or ASA-4 according to the American Society of Anaesthesiology were excluded.

Patients with complicated cholelithiasis were also excluded: 52 (7.6\%) with acute cholecystitis, 53 (7.8\%) with acute pancreatitis and $4(0.6 \%)$ with acute cholecysto-pancreatitis. Additionally, three patients with achalasia and one with microspherocytosis were excluded.

The remaining 442 patients (65\%) were divided into two groups:

-Group A: three hundred and sixty-two patients (82\%) with simple, non-complicated cholelithiasis.

-Group B: eighty patients (18\%) who had cholelithiasis and GERD.
Table II. Upper GI endoscopy in group B (80 patients)

\begin{tabular}{lc}
\hline Upper Gl endoscopy, n (\%) & $80(100 \%)$ \\
\hline Hiatal hernia, n (\%) & $80(100 \%)$ \\
No esophagitis (*), n (\%) & $9(11.2 \%)$ \\
Esophagitis A, n (\%) & $22(27.6 \%)$ \\
Esophagitis B, n (\%) & $26(32.5 \%)$ \\
Esophagitis C, n (\%) & $17(21,2 \%)$ \\
Esophagitis D + estenosis & $2(2.5 \%)$ \\
Barrett's esophagus, n (\%) & $4(5 \%)$ \\
Functional studies (altered pHmetry)* & $9(11.2 \%)$ \\
\hline
\end{tabular}

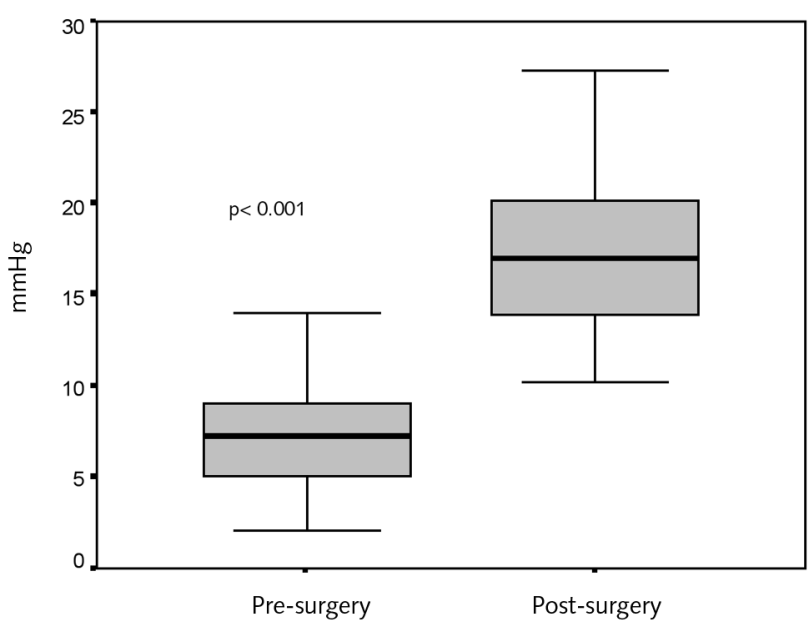

Fig. 1. Lower esophageal sphincter (LES) pressure in group B. Presiones en EEI pre y post-cirugía en el grupo $B$.

Conversion of laparoscopic to open cholecystectomy was not necessary in any patients in both groups.

Clinical and demographic data for both groups are shown in table I. When compared to patients in group A, group B patients were more frequently males and older than 75 years, weighed more, and more often were hypertensive. 
The preoperative endoscopic findings observed in group B are shown in table II. Following the "Los Angeles classification", we found different grades of esophageal lesions in all patients, except in 9 cases who had normal endoscopy but, abnormal 24-hour pHmetry.

These functional studies were repeated in all group B patients after surgery. Lower esophageal sphincter (LES) pressures increased from 7.2 $\pm 2.8 \mathrm{mmHg}$ (range, 2.1-14 $\mathrm{mmHg}$ ), in the preoperative period, to $17.4 \pm 4 \mathrm{mmHg}$ (range, $10.2-27.3 \mathrm{mmHg}$; $\mathrm{p}<0.05$ ) after surgery (Fig. 1). Similarly, a normalization of the percentage of exposure to acid in the post-surgical determination $[2.5 \pm 1.2$ (range, 0,1-4)] and the De Meester score $[9.4 \pm 5.25$ (range, 3.4 - 14.1)] was observed in all patients.

From a clinical point of view, a complete resolution of symptoms due to reflux was observed. Only one patient (2\%) developed dysphagia for solid food (everyday, but not at all mealtimes) in the late postoperative period (6 months), and a sensation of trapped air persisting at 6 months occurred in two patients (4.1\%), causing discomfort (not everyday). These three patients were asymptomatic at 12 months after the surgery.

With respect to intraoperative incidences, no significant differences were observed between both groups of patients. In relation to the rate of complications and the surgical manoeuvres performed, only the duration of surgery reached statistical signification [group A, $48 \pm 25 \mathrm{~min}$ (range, $10-150 \mathrm{~min}$ ); group B $112 \pm 23$ min (range, 80-180 min), $\mathrm{p}<0.001]$ (Table III) (Fig. 2).

Likewise, no significant differences were observed in the macroscopic appearance of the gallbladder wall which could cause technical difficulties at the time of surgery and therefore could determine an increase in the complications number of one group or another (Table IV).

On the other hand, no differences were observed in the onset of oral tolerance as patients tolerated oral ingestions within the first 24 hours.

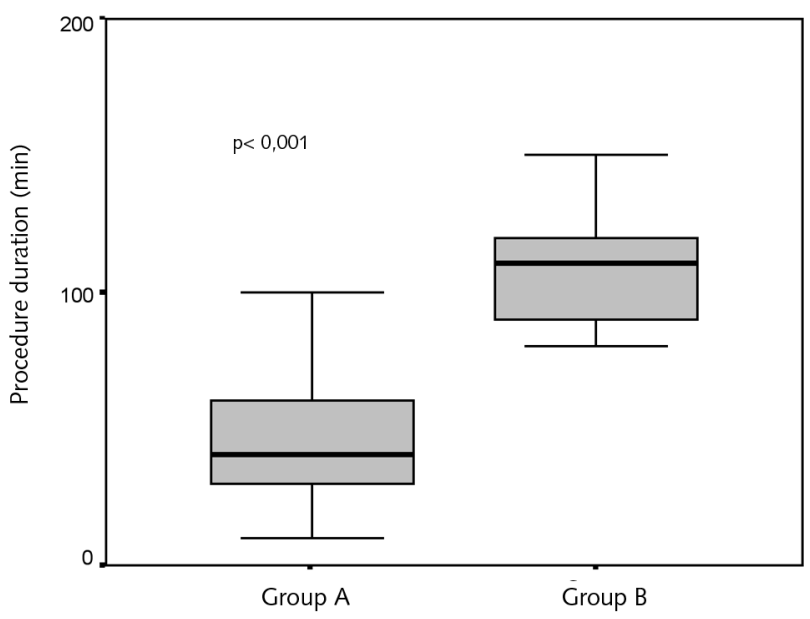

Fig. 2. Procedure duration.

Tiempo operatorio.
Table III. Intraoperative incidences

\begin{tabular}{lccc}
\hline & Group A (n=362) & Group B $(n=80)$ & $p$ \\
\hline $\begin{array}{l}\text { Operation duration (min) } \\
\quad \text { (range) }\end{array}$ & $48 \pm 25(10-150)$ & $112 \pm 23(80-180)$ & $<0.001$ \\
Emptying of gallbladder, $\mathrm{n}(\%)$ & $35(9.7 \%)$ & $3(3.7 \%)$ & NS \\
Removal of adherences, $\mathrm{n}(\%)$ & $215(59.4 \%)$ & $32(40 \%)$ & NS \\
Subhepatic drainage, $\mathrm{n}(\%)$ & $14(3.9 \%)$ & $3(3.7 \%)$ & NS \\
\hline
\end{tabular}

However, differences were significant in the number of days needed to return to normal daily activities [group A, 5.8 \pm 0.89 days (range, $4-10$ days); group $\mathrm{B}, 6.5 \pm 1$ days (range, 5-10 days), p<0.001] (Fig. 3).

Regarding the hospitalization stay, in group A, 327 patients $(90.3 \%)$ were discharged within the first 24 hours, 30 patients $(8.3 \%)$ within 48 hours and 5 patients $(1.4 \%)$ within 72 hours.

In group B, 67 patients $(83.8 \%)$ were discharged within the first 24 hours, 10 patients $(12.5 \%)$ within 48 hours, and 3 patients (3.7\%) after 72 hours. Hospital stay did not therefore exceed 72 hours, in either group.

Postoperative complications were few for both groups: acute pancreatitis occurred in one case $(0.3 \%)$ and cystic biliary fistula in another patient $(0.3 \%)$ in group A.

Table IV. Macroscopic intraoperative findings

\begin{tabular}{lccc}
\hline & $\begin{array}{c}\text { Group A } \\
(n=362)\end{array}$ & $\begin{array}{c}\text { Group B } \\
(n=80)\end{array}$ & $p$ \\
\hline Scleroatrophic gallbladder & $74(20.4 \%)$ & $8(10 \%)$ & NS \\
Gallbladder hydrops & $25(6.9 \%)$ & $6(7.5 \%)$ & NS \\
Normal gallbladder wall & $263(72.7 \%)$ & $66(82.5 \%)$ & NS \\
\hline
\end{tabular}

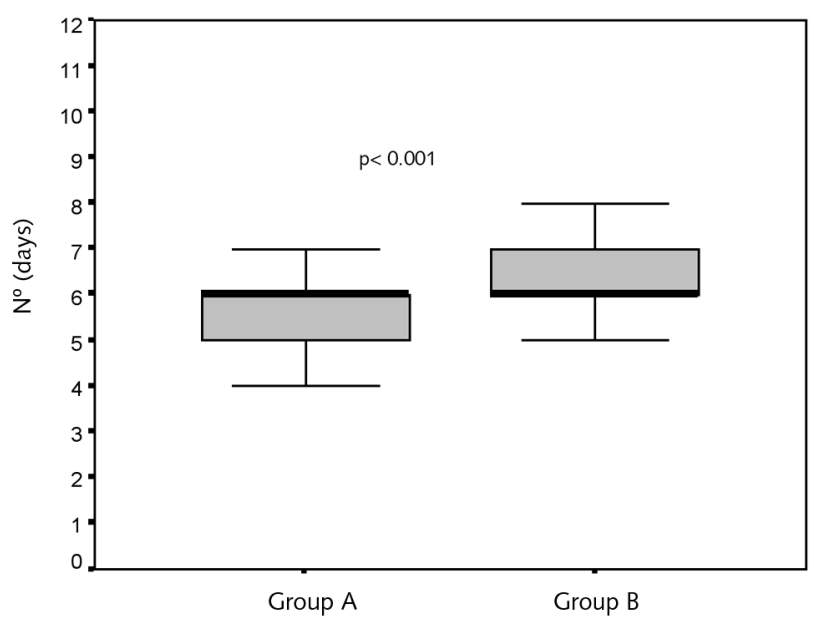

Fig. 3. Number of days necessary for returning to normal daily activities.

Recuperación actividad habitual. 


\section{DISCUSSION}

Recent studies have shown that an ASA $>2$ (15), but not age, is the main factor associated with a greater number of complications in the postoperative period. Age over 80 years, ASA group greater than two, and the presence of choledocholithiasis are all factors associated with a greater conversion rate to open surgery and longer hospital stay in patients with cholecystitis (16). We therefore tried that no differences existed between study groups in this sense. Thus, we attempted to select a group of patients as homogeneous as possible, and only group B included patients that were older and more often obese. In spite of this, these factors did not influence surgery results.

In the light of these studies $(15,16)$, it is possible that age is a variable of lesser importance. We speculate that, in our study, if we had used only the ASA classification as the main exclusion criteria for combined surgery, perhaps results would have been similar. The evaluation of the rate of complications in patients with ASA greater than II, or complicated cholecystopathy (cholecystitis, pancreatitis, or both) needs to be further investigated.

This leads one to wonder, whether associated surgery should be performed in patients with a high surgical risk, when data exist that surgery for cholecystitis in patients with ASA > II is associated with greater morbidity and mortality (15). Extend the procedure duration is likely not recommendable in these cases.

According to our results, we may conclude that performing both procedures within one single surgery may be recommended in all patients with low anesthetic risk where surgery is indicated for both conditions (choleli-thiasis and GERD), with the aim of solving them with no added risks. Furthermore, it is likely that the outcome of the surgery will be more satisfactory, since reflux will disappear after a combined procedure. We do not believe that, at present, this surgery should be indicated to all patients, since those with a high surgical risk (ASA > II) and those who have complicated cholelithiasis may have a greater risk of complications. Such patients include usually older subjects and those where proton-pump inhibitor therapy may adequately control GERD-derived symptoms.

\section{REFERENCES}

1. Dubois F, Berthelot G, Levard H. Laparoscopic cholecystectomy: historic perspective and personal experience. Surg Laparosc Endosc 1991; 1: 52-7.

2. Cuschieri A, Dubois F, Mouiel J, Mouret P, Becker H, Buess G, et al. The European experience with laparoscopic cholecystectomy. Am J Surg 1991; 161: 385-7.

3. Berci G, Jackier JM. The Los Angeles experience with laparoscopic cholecystectomy. Am J Surg 1991; 161: 382-4.

4. Airan M, Appel M, Berci G, Coburg AJ, Cohen M, Cuschieri A, et al. Retrospective and prospective multi-institutional laparoscopic cholecystectomy study organized by the Society of American Gastrointestinal Endoscopic Surgery. Surg Endosc 1992; 6: 16976.

5. Flowers JL, Bailey RW, Scovill WA, Zucker KA. The Baltimore experience with laparoscopic management of acute cholecystitis. Am J Surg 1991; 161: 388-92.

6. Schrenk P, Woisetschläger R, Wayand U. Laparoscopic cholecystectomy. Cause of conversions in 1300 patients and analysis of risk factors. Surg Endosc 1995; 9: 25-8.

7. Lo CM, Liu CL, Fan ST, Lai ECS, Wong J. Prospective randomized study of early versus delayed laparoscopic cholecystectomy for acute cholecystitis. Ann Surg 1998; 227: 461-7.

8. Hannan EL, Imperato PJ, Nenner RP, Starr H. Laparoscopic and open cholecystectomy in New York State: mortality, complications and choice of procedure. Surgery 1999; 125: 223-31.

9. Portincasa P, Di Ciaula A, Palmieri V, Velardi A, VanBerge-Henegouwen GP, Palasciano G. Impaired gallbladder and gastric motility and pathological gastro-oesophageal reflux in gallstone patients. Eur J Clin Invest 1997; 27 (8): 653-61.

10. Rothwell JF, Lawlor P, Byrne PJ, Walsh TN, Hennessy TP. Cholecystectomy-induced gastroesophageal reflux: is it reduced by the laparoscopic approach? Am J Gastroenterol 1997; 92 (8): 1351-4.

11. McNamara DA, O'Donohoe MK, Horgan PG, Tanner WA, Keane FB. Symptoms of oesophageal reflux are more common following laparoscopic cholecystectomy than in a control population. Ir J Med Sci 1998; 167 (1): 11-3.

12. Csendes A, Csendes P, Rojas J, Sánchez Sánchez M. Results of cholecystectomy realized 10 years ago. Rev Med Chil 2000; 128 (12): 1309-12.

13. Gushcha AL, Baulin SS, Podiablonskaia IA. Reflux esophagitis in cholecystitis. Vestn Khir Im I I Grek 1993; 150 (3-4): 21-5.

14. Pozo F, Giganto F, Rodrigo L. Clinical efficacy of the Toupet technique performed by laparoscopic surgery. Medium-term follow-up in 122 cases. Surg Endosc 2001; 15: 1171-4.

15. Brunt LM, Quasebarth MA, Dunnegan DL, Soper NJ. Outcomes analysis of laparoscopic cholecystectomy in the extremely elderly. Surg Endosc 2001; 15 (7): 700-5.

16. Leardi S, Delmonaco S, Maira E, Pietroletti R, Chiaretti M, De Milito R, et al. Acute cholecystitis in patients over 70 years old Minerva Chir 2001; 56 (5): 501-6. 


\title{
Colelitiasis no complicada asociada con ERGE. Resultados de la cirugía laparoscópica combinada en pacientes con bajo riesgo quirúrgico
}

\author{
F. Pozo, F. Giganto y L. Rodrigo ${ }^{2}$ \\ Servicio de Cirugía General y del Aparato Digestivo. ${ }^{1}$ Unidad de Motilidad. ${ }^{2}$ Servicio de Aparato Digestivo. Hospital \\ Central de Asturias. Oviedo
}

\section{RESUMEN}

Objetivos: el objetivo del presente estudio fue la valoración de la eficacia de la cirugía laparoscópica combinada de la colelitiasis no complicada y de la enfermedad por reflujo gastroesofágico (ERGE) en pacientes con bajo riesgo quirúrgico.

Métodos: desde febrero de 1991 a febrero de 2002 se realizaron 680 colecistectomías mediante cirugía laparoscópica, cumpliendo criterios de inclusión para el presente estudio un total de 442 pacientes que fueron divididos en dos grupos: grupo A: colelitiasis no complicada (colecistectomía sola) con un total de 362 pacientes y grupo B: colelitiasis no complicada y ERGE (colecistectomía y reparación hiatal con funduplicatura tipo Toupet) en 80 pacientes. En todos los pacientes se recogieron de forma prospectiva y se compararon datos demográficos y clínicos, incidencias peroperatorias y complicaciones post-intervención.

Los resultados de la cirugía del reflujo (grupo B) se valoraron a los seis meses de la misma mediante la realización de manometría y pH-metría de 24 horas.

Resultados: aunque en el grupo sometido a cirugía combinada los pacientes eran más obesos y de más edad ( $p<0,05)$, no encontramos diferencias significativas en las incidencias peroperatorias ni en las complicaciones post-intervención en ambos grupos. Sólo se encuentran diferencias significativas en la duración de la intervención: $48 \pm 25$ min (10-150) en el grupo A vs $112 \pm 23$ min (80-180) en el grupo B ( $<<0,001)$, así como en la vuelta a su actividad cotidiana normal: 5,8 $\pm 0,9$ días en el grupo $\mathrm{A}$ us 6,5 \pm 1 días en el grupo $B(p<0,001)$. En este último grupo comprobamos la normalización de los valores de pH-metría de 24 horas en todos los casos al sexto mes, con ausencia de síntomas asociados a reflujo.

Conclusiones: en pacientes menores de 75 años y de bajo riesgo quirúrgico con colelitiasis simple (no complicada) y ERGE, ambas patologías pueden solucionarse en el mismo acto quirúrgico por vía laparoscópica sin aumentar riesgos ni complicaciones postoperatorias.

Palabras clave: Colecistectomía laparoscópica. Reflujo gastroesofágico. Funduplicatura de Toupet. Cirugía endoscópica.

\section{INTRODUCCIÓN}

En la última década se ha establecido la cirugía endoscópica como el tratamiento de elección de la litiasis biliar sintomática tanto en su forma de presentación simple como complicada (1-5). Existen además distintas caracte- rísticas tanto en el paciente -edad, clasificación según los criterios de la American Society of Anaesthesiology (ASA) - como en la forma de presentación, que pueden influir en la decisión del abordaje endoscópico, o bien, una vez indicado este, su conversión a cirugía abierta (6-8).

Por otra parte, conocemos que existe un subgrupo de pacientes con colelitiasis, que presentan patología asociada en el tracto gastrointestinal superior, entre ellas el reflujo gastroesofágico (ERGE) (9).

También existen publicaciones que nos informan que la propia cirugía de la colelitiasis, tanto por vía laparoscópica como abierta, es causa por sí misma de la aparición o empeoramiento del ERGE (10) y que los síntomas de reflujo son más comunes después de una colecistectomía por vía laparoscópica que en el resto de la población (11). Por lo tanto, parte del fracaso clínico que sufren algunos pacientes que se someten a colecistectomía, podría ser debido a la existencia de ERGE asociado (11-13).

Parece razonable, antes de una intervención por colelitiasis simple, si existen síntomas de ERGE, estudiar el paciente adecuadamente e intentar solucionar ambas patologías en el mismo acto quirúrgico. De esta forma se podría evitar la necesidad de tratamientos posteriores o una segunda intervención.

Antes de la llegada de la cirugía endoscópica, nuestro grupo realizaba, siempre que fuera posible y si las características del paciente lo permitían, cirugía combinada en el mismo acto quirúrgico. Incluso, en los primeros años de difusión de la técnica endoscópica, la existencia de hernia de hiato o ERGE contraindicaba el abordaje endoscópico de la vesícula biliar, y los pacientes se operaban por laparotomía.

Nuestra intención ha sido valorar los resultados quirúrgicos en un grupo de pacientes con bajo riesgo quirúrgico -según criterios ASA-y menores de 75 años, a los que se les trató de solucionar mediante cirugía endoscópica las dos patologías (colelitiasis y ERGE).

Para poder realizar una valoración correcta, comparamos este grupo con otro de similares características clínicas que tan sólo fueron intervenidos de colelitiasis no complicada. 


\section{MATERIAL Y MÉTODOS}

Desde febrero de 1991 a febrero de 2002, realizamos colecistectomía endoscópica a un total de 680 pacientes de forma consecutiva y todos ellos fueron operados por el mismo cirujano (FP).

El protocolo del estudio incluía: características demográficas de los pacientes, historia clínica, exploración física, duración de los síntomas, pruebas biológicas (hemograma, coagulación y bioquímica elemental con pruebas de función hepática), electrocardiograma, radiografía de tórax y ecografía abdominal. En los casos que los pacientes referían clínica sugestiva de ERGE se realizaba endoscopia digestiva alta para confirmar el diagnóstico; si no existían lesiones erosivas se realizaba $\mathrm{pH}$-metría de 24 horas tras localización del EEI mediante manometría estacionaria. Esta prueba se realizó también a todos los pacientes con esofagitis antes de ser intervenidos.

La manometría y pH-metría esofágicas se repitieron 6 meses después de la intervención, a todos los pacientes operados de ERGE.

Además se recogieron los detalles de la intervención y los acontecimientos post-intervención, también de forma prospectiva. El tiempo operatorio se contabilizó desde la incisión cutánea, hasta la sutura de la misma.

La manometría esofágica, para localización de la parte superior del esfínter esofágico inferior (EEI), se realizó con un sistema de perfusión hidroneumocapilar de baja distensibilidad, empleando un catéter con cuatro orificios separados $5 \mathrm{~cm}$ entre sí, con orientación radial.

Para realizar la pH-metría esofágica de 24 horas se utilizó un registrador ambulatorio Mark III (Synectics Medical, Irving, Tx), con una frecuencia de registro cada 4 segundos, conectado a un electrodo de antimonio monocristalino colocado $5 \mathrm{~cm}$ por encima de la parte superior del EEI, previamente localizada por manometría esofágica, y después de calibración de la sonda a pH 1,07 y 7,01. Consideramos la prueba patológica cuando el porcentaje de exposición ácida total en tercio distal supera el $4 \%$ y/o el score de De Meester estaba por encima de 14,24 puntos.

En todos los casos se descartó la existencia de trastorno motor primario (acalasia, espasmo difuso,...), que pudieran justificar alguno de los síntomas del paciente.

En caso de sospecha clínica, analítica y/o ecográfica de coledocolitiasis se practicó colangiografía retrógrada y esfinterotomía endoscópicas para extracción de los cálculos de la vía biliar principal.

\section{Criterios de inclusión}

Los pacientes fueron divididos en dos grupos de acuerdo con los siguientes criterios:

Grupo A (colelitiasis simple no complicada). Pacientes con clínica de cólicos hepáticos de repetición -dolor intenso en epigastrio y/o hipocondrio derecho- con ecografía que demuestra la existencia de litiasis biliar o mi- crolitiasis, definida por la existencia de focos ecogénicos con sombra acústica (no en el caso de la microlitiasis) y que son móviles, situándose en posición de declive.

Grupo B (pacientes con los mismos criterios que los del grupo A y que además tenían ERGE). Demostrada mediante endoscopia digestiva alta y/o $\mathrm{pH}$-metría esofágica de 24 horas, y que no tenían un estricto control de sus síntomas a pesar de tratamiento médico adecuado (generalmente con inhibidores de la bomba de protones). Cumplieron estos criterios 80 pacientes.

Se consideraron criterios de exclusión de este grupo: coledocolitiasis no resuelta endoscópicamente, sospecha de carcinoma de vesícula, coexistencia con otra patología que precisase cirugía abierta, discrasias sanguíneas no tratables, edad mayor de 75 años y el pertenecer a un grupo ASA III o IV, así como la existencia de antecedente de pancreatitis y/o colecistitis. No se excluyeron los casos de coledocolitiasis si esta era resuelta mediante esfinterotomía endoscópica. Cumplieron estos criterios 362 pacientes.

\section{Técnica quirúrgica}

Tanto en el grupo A como en el grupo B, se realizó colecistectomía mediante técnica quirúrgica propuesta por Dubois (1), con variantes dependiendo de la anatomía del paciente y la existencia de cirugía previa en el espacio supramesocólico.

En el grupo B a todos los pacientes se les realizó la misma técnica: sutura retroesofágica de los pilares diafragmáticos y funduplicatura posterior a lo Toupet para solucionar su ERGE, además de colecistectomía. Esta técnica ha sido descrita en una publicación anterior de nuestro grupo (14).

Todos los pacientes recibieron profilaxis antibiótica (amoxicilina $1 \mathrm{~g}$ y ácido clavulánico $125 \mathrm{mg}$ ) en la inducción anestésica, y profilaxis tromboembólica con HBPM que se mantenía durante diez días después de la operación.

Todos los pacientes fueron operados por el mismo cirujano (FP) después de que este ya hubiese realizado sus primeros 180 casos de colecistectomía endoscópica.

\section{Análisis estadístico}

El estudio estadístico se llevó a cabo mediante tablas de contingencia y test de la Chi cuadrado en el caso de variables cualitativas y mediante la t de Student para variables cuantitativas. Se consideraron diferencias significativas cuando el valor de $\mathrm{p}$ fue menor de 0,05.

\section{RESULTADOS}

Del total de los 680 pacientes intervenidos de forma consecutiva, $125(18,4 \%)$ eran pacientes con edad mayor de 75 años y/o un ASA III o IV, según la clasificación de 
la American Society of Anaesthesiology, por lo que no se tuvieron en cuenta a la hora de realizar el análisis.

De la misma forma se excluyeron los pacientes con colelitiasis complicada: $52(7,6 \%)$ con antecedente de colecistitis, $53(7,8 \%)$ de pancreatitis y $4(0,6 \%)$ de colecistopancreatitis.

También se excluyeron del análisis tres pacientes con acalasia y uno al que se realizó esplenectomía por estar afecto de microesferocitosis $(0,6 \%)$.

$\mathrm{El}$ resto de los $442(65 \%)$ pacientes fueron divididos en 2 grupos:

_Grupo A: 362 pacientes (82\%) con colelitiasis simple (no complicada).

-Grupo B: 80 pacientes (18\%) que además de presentar colelitiasis simple, tenían ERGE con criterios quirúrgicos.

En ningún caso de estos dos grupos de pacientes hubo necesidad de conversión a cirugía abierta.

Los datos demográficos y clínicos de ambos grupos se muestran en la tabla I. En ella se pone de manifiesto una mayor proporción de hombres que de mujeres en el grupo de cirugía combinada, así como la existencia de mayor edad, más peso y un mayor número de pacientes con hipertensión arterial.

Los hallazgos endoscópicos preoperatorios de los pacientes incluidos en el grupo B se muestran en la tabla II: encontramos lesiones de esofagitis en distintos grados de la clasificación de Los Ángeles en todos los pacientes menos en 9 de ellos, a los que se les realizó además de la manometría preoperatoria una $\mathrm{pH}$-metría de 24 horas que resultó patológica.

Estas técnicas funcionales se repitieron a todos los pacientes del grupo B, seis meses después de la cirugía, observando una elevación de la presión en el EEI: de 7,2 \pm $2,8 \mathrm{mmHg}(2,1-14)$ en el preoperatorio a $17,4 \pm 4 \mathrm{mmHg}$ $(10,2-27,3)$ después de la operación, con una $\mathrm{p}<0,05$ (Fig. 1). De la misma forma se observa también una normalización del porcentaje de exposición ácida en la determinación post-cirugía: $2,5 \pm 1,2(0,1-4)$ y del score de De Meester: $9.4 \pm 5.25(3,4-14,1)$, en todos los pacientes.
Desde el punto de vista clínico se observó una resolución completa de la sintomatología debida al reflujo. En tan sólo un caso se observó la aparición de disfagia para alimentos sólidos (todos los días pero no en todas las comidas) en el postoperatorio tardío (seis meses): 1/80 $(1,2 \%)$, y sensación de atrapamiento aéreo en dos pacientes que también persistía a los seis meses produciendo molestias (no diarias) 2/80 (2,5\%). Los tres pacientes quedaron asintomáticos a los doce meses de la operación.

En cuanto a las incidencias peroperatorias no se observan diferencias significativas. Respecto a las complicaciones surgidas y maniobras quirúrgicas realizadas, sólo el tiempo de duración de la intervención, $48 \pm 25 \mathrm{~min}$ (10-150) en el grupo A vs $112 \pm 23 \min$ (80-180) en el grupo $\mathrm{B}$, presenta diferencias significativas con una $\mathrm{p}<0,001$ (Tabla III) (Fig. 2).

De la misma forma no se observaron diferencias significativas en el estado de la pared de la vesícula desde el punto de vista macroscópico que pudieran condicionar una dificultad técnica en la realización de la cirugía y por lo tanto un aumento de las complicaciones en uno u otro grupo (Tabla IV).

Por otra parte, tampoco se han observado diferencias en el comienzo de la tolerancia oral ya que la totalidad de los pacientes toleraban durante las primeras 24 horas.

Sin embargo, sí se observaron diferencias en los días en que tardaban en volver a su actividad cotidiana normal (alta laboral): $5,8 \pm 0,89$ (4-10) en el grupo A vs 6,5 \pm 1 (5-10) en el grupo B, con una $\mathrm{p}<0,001$ (Fig. 3).

En cuanto al tiempo de hospitalización en el grupo A, el 90,3\% (327 pacientes) fueron dados de alta en las primeras 24 horas, el 8,3\% (30 pacientes) en 48 horas y el $1,4 \%$ restante ( 5 pacientes) en 72 horas.

En el grupo B el 83,8\% (67 pacientes) fueron dados de alta hospitalaria en las primeras 24 horas, el 12,5\% (10 pacientes) en 48 horas y el 3,7\% (3 pacientes) en 72 horas. En ninguno de los grupos la estancia hospitalaria superó las 72 horas.

Las complicaciones postoperatorias han sido escasas en ambos grupos ya que sólo hemos observado una pan-

Tabla I. Datos demográficos y clínicos

\begin{tabular}{|c|c|c|c|}
\hline & Grupo A $(n=362)$ & Grupo $B(n=80)$ & $p$ \\
\hline Edad (media $\pm \mathrm{DE})$ & $49,6 \pm 13(19-75)$ & $56 \pm 11(32-74)$ & $<0,05$ \\
\hline Sexo $(M / H)$, proporción & $251 / 111=2,3 / 1$ & $35 / 45=1,1 / 1,3$ & $<0,05$ \\
\hline $\mathrm{N}^{\circ}$ de embarazos (media $\pm \mathrm{DE}$ ) & $1,4 \pm 1,5(1-5)$ & $1 \pm 1,3(1-11)$ & NS \\
\hline $\mathrm{BMl}<25\left(\mathrm{~kg} / \mathrm{m}^{2}\right), \mathrm{n}(\%)$ & $60(16,6 \%)$ & $2(2,5 \%)$ & $<0,05$ \\
\hline BMI 25-30, n (\%) & $122(33,7 \%)$ & $23(28,7 \%)$ & $<0,05$ \\
\hline BMI 30-40, n (\%) & $130(35,9 \%)$ & $36(45 \%)$ & $<0,05$ \\
\hline $\mathrm{BMI}>40, \mathrm{n}(\%)$ & $50(13,8 \%)$ & $19(23,8 \%)$ & $<0,05$ \\
\hline Peritonitis previa, n (\%) & $21(5,8 \%)$ & $3(3,7 \%)$ & NS \\
\hline Laparotomía supraumbilical previa & $7(1,9 \%)$ & $1(1,2 \%)$ & NS \\
\hline Laparotomía infraumbilical previa & $94(26 \%)$ & $11(13,7 \%)$ & NS \\
\hline Tiempo de inicio de clínica (semanas) (media $\pm D E$ ) (rango) & $43 \pm 35,4(1-99)$ & $42 \pm 34,7(2-99)$ & NS \\
\hline Diabetes, n (\%) & $13(3,6 \%)$ & $2(2,5 \%)$ & NS \\
\hline HTA, n (\%) & $31(8,6 \%)$ & $16(20 \%)$ & $<0,05$ \\
\hline
\end{tabular}


Tabla II. Hallazgos endoscópicos en el grupo B (80 pacientes)

\begin{tabular}{lc}
\hline Gastroscopia, $n(\%)$ & $80(100 \%)$ \\
\hline Hernia hiatal, $\mathrm{n}(\%)$ & $80(100 \%)$ \\
No esofagitis (*), n (\%) & $9(11,2 \%)$ \\
Esofagitis A, n (\%) & $22(27,6 \%)$ \\
Esofagitis B, n (\%) & $26(32,5 \%)$ \\
Esofagitis C, n (\%) & $17(21,2 \%)$ \\
Esofagitis D + estenosis & $2(2,5 \%)$ \\
Esófago de Barrett, n (\%) & $4(5 \%)$ \\
Estudios funcionales (pH-metría alterada) $\left(^{*}\right)$ & $9(11,2 \%)$ \\
\hline$\left.{ }^{*}\right)$ pH-metría alterada, n (\%) &
\end{tabular}

Tabla III. Incidencias peroperatorias

\begin{tabular}{|c|c|c|c|}
\hline & $\begin{array}{l}\text { Grupo A } \\
(n=362)\end{array}$ & $\begin{array}{c}\text { Grupo B } \\
(n=80)\end{array}$ & $p$ \\
\hline $\begin{array}{l}\text { Tiempo operatorio } \\
\text { (minutos) (rango) }\end{array}$ & $48 \pm 25(10-150)$ & $112 \pm 23(80-180)$ & $<0,001$ \\
\hline Vaciado de vesícula, n (\%) & $35(9,7 \%)$ & $3(3,7 \%)$ & NS \\
\hline Liberación adherencias, n (\%) & 6) $215(59,4 \%)$ & $32(40 \%)$ & NS \\
\hline Drenaje subhepático, n (\%) & $14(3,9 \%)$ & $3(3,7 \%)$ & NS \\
\hline
\end{tabular}

Tabla IV. Hallazgos macroscópicos en la pared vesícula biliar

\begin{tabular}{lccc}
\hline & $\begin{array}{c}\text { Grupo A } \\
(n=362)\end{array}$ & $\begin{array}{c}\text { Grupo B } \\
(n=80)\end{array}$ & $p$ \\
\hline Vesícula escleroatrófica & $74(20,4 \%)$ & $8(10 \%)$ & NS \\
Hidrops vesicular & $25(6,9 \%)$ & $6(7,5 \%)$ & NS \\
Pared normal & $263(72,7 \%)$ & $66(82,5 \%)$ & NS \\
\hline
\end{tabular}

creatitis aguda $(0,3 \%)$-paciente con esfinterotomía endoscópica y extracción de cálculos tres días antes de la colecistectomía endoscópica- y una fístula biliar del muñón cístico, exteriorizada por drenaje $(0,3 \%)$, en el grupo A.

\section{DISCUSIÓN}

Existen trabajos recientes que ponen de manifiesto que el grupo ASA > II y no la edad, es el factor que se asocia a un mayor número de complicaciones en el postoperatorio (15), y que con edad por encima de los 80 años, este mismo grupo ASA, y la existencia de coledocolitiasis habría una mayor tasa de conversión a cirugía abierta y una estancia hospitalaria de mayor duración en pacientes con colecistitis (16). En nuestro estudio intentamos que no existieran diferencias en los grupos en este sentido. Así fueron seleccionados para una comparación lo más homogénea posible y tan sólo en el grupo B se muestra que los pacientes tenían más edad y eran más obesos, pero estos hechos no han influido en los resultados de la cirugía.

A la vista de estos artículos citados $(15,16)$ es posible que la edad sea un factor que se pudiera haberse obviado, teniendo en cuenta sólo el grupo ASA como criterio de exclusión, y quizás también los resultados hubiesen sido similares.

Queda para posteriores estudios la valoración de complicaciones en un grupo de pacientes con ASA elevado y con colecistopatía complicada (colecistitis, pancreatitis, o ambas). ¿Se debe de realizar cirugía asociada en pacientes de alto riesgo quirúrgico, cuando hay datos de que la cirugía de la colecistitis en pacientes con ASA>II se asocia con una mayor morbi-mortalidad? (15). El añadir tiempo de intervención, posiblemente no sea lo más recomendable en estos casos.

Tan sólo añadir que en el grupo intervenido únicamente de colelitiasis, no se observó en ningún caso la existencia de ERGE en el tiempo de seguimiento, ni otros síntomas relacionados tradicionalmente con el llamado síndrome post-colecistectomía.

De todas formas con los resultados de este trabajo podemos señalar que es recomendable, ante todo paciente con bajo riesgo quirúrgico que va a ser sometido a cirugía de colelitiasis no complicada, realizar una anamnesis cuidadosa sobre síntomas de ERGE. Con fundamento clínico se deben realizar los estudios necesarios (endoscopia, pH-metría y manometría esofágicas) y si se confirma la existencia de ERGE, debemos plantear al paciente su solución en el mismo acto quirúrgico, con la seguridad de que sólo se añade tiempo a la estancia dentro del quirófano y algo de tiempo en la recuperación de la actividad cotidiana normal, pero no se incrementa el número o la importancia de las complicaciones.

De la misma forma podemos afirmar que es muy probable que los resultados de la cirugía a la que se va a someter, pudieran resultar más satisfactorios, ya que el reflujo desaparecerá tras la intervención combinada.

No creemos que se deba indicar esta cirugía por el momento a todos los pacientes, ya que los enfermos con riesgo quirúrgico elevado y los que tienen colelitiasis complicada podrían tener mayor riesgo de complicaciones. Estos pacientes suelen ser los de mayor edad y en los que un tratamiento con inhibidores de la bomba de protones, en la mayoría de los casos, es capaz de controlar adecuadamente la sintomatología derivada de su enfermedad por reflujo. 